(An Initiative of International Center for Research and Resources Development)

ISSN Number: 2773-5958, SSM Number: 201901038138(1347468-T), www.icrrd.com

\title{
An Assessment of Poultry Rearing and Hygienic Management of Broiler Farms of Cox's Bazar District in Bangladesh
}

\author{
*Hamida Khanom¹, Ashraful Hoque ${ }^{2}$, Md Rabiul Islam³ ${ }^{3}$, Rasel Prank ${ }^{4}$, Mohammad Mahmudul \\ Hassan $^{5}$, Md. Abdul Alim6
}

1234 Faculty of Veterinary Medicine, Chattogram Veterinary \& Animal Sciences University (CVASU), Khulshi, Chattogram-4225, Bangladesh, Email: hamidakhanom21@gmail.com, ashraful.cvasu@gmail.com , $\underline{\text { mdrabiulislam97@gmail.com, raselprank68@gmail.com }}$

5 Professor, Department of Physiology, Biochemistry \& Pharmacology, Faculty of Veterinary Medicine, Chattogram Veterinary \& Animal Sciences University (CVASU), Khulshi, Chattogram-4225,

Bangladesh. Email: miladhasan@yahoo.com

6 Associate Professor, Department of Pathology \& Parasitology, Faculty of Veterinary Medicine, Chattogram Veterinary \& Animal Sciences University (CVASU), Khulshi, Chattogram-4225,

Bangladesh, Email: maalim85@gmail.com

*Corresponding author
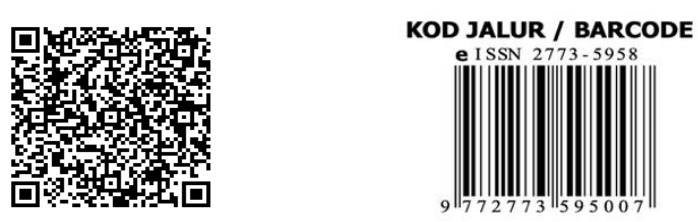

Date Received: 28 April 2021
Date Accepted: 18 May 2021
Date Published: 24 May 2021
Volume -2, Issue-2, May 2021
( ICRRD HIGH INDEX RESEARCH JOURNAL.

Abstract: Poultry industry is one of the most booming industry in the Cox's bazar district. This study was carried out to assess the hygienic practices and also to improve the broiler meat safety. Currently, every country in the world is increasing their effort to improve food safety to reduce the food safety risk. The data for this study was collected from the desk research, observation, survey, and interviews of poultry farmers. Twenty broiler farmers were surveyed by using questionnaire. The study revealed that the majority of the farmers are doing broiler farming as their main source of income. The flock size is around 501-1000 of the larger number of farms and on an average farmers are rearing 5.57 cycles per year. The study recommended some implication to improve hygienic practices of broiler and to reduce the foodborne illness of the district as well.

Keywords: Poultry Industry, Broiler Farms, Hygienic Management, Foodborne Illness. 


\section{Introduction}

Bangladesh has a long historical record of poultry rearing under traditional of backyard farming. In the beginning, commercial poultry farming started in small scale and got poor rural women and unemployed youth involved and thus employed. Commercial poultry production has been growing in Bangladesh since early in 1990 using improved genetics, manufactured feeds and management. The dramatic growth of poultry farm throughout the country has taken place without judging feasibility of the farm area. (S.K.Raha, 2013)The sector accounts for $14 \%$ of the total value of livestock output. It is found out that poultry meat alone contributes $37 \%$ of the total meat production.

\begin{tabular}{|c|c|}
\hline No of GP Farms in operation & 16 (8 companies) \\
\hline No of listed breeder Farms & 206 (small and large) \\
\hline Production of broiler DOC(weekly production) & $\begin{array}{c}\text { Around one crore seventy } \\
\text { thousand (at present) }\end{array}$ \\
\hline No of Commercial Farms & $65-70$ thousand \\
\hline Per capita broiler meat consumption is & Yearly $6.3 \mathrm{~kg}$ \\
\hline $\begin{array}{c}\text { In 2020 per capita poultry meat consumption is expected to be } \\
\text { reached }\end{array}$ & Around 40\% \\
\hline In 2020 the contribution of poultry meat could increase to $7 \mathrm{~kg}$ \\
\hline
\end{tabular}

Source: (Poultry at a glance:Worlds Poultry Science Association, n.d)

Poultry contributes about 22-27\% of the total animal protein supply in the country. (Holfarce, 2002)Biosecurity on poultry farm comprises all measure taken to minimize the risk of the introduction and spread of infectious agent. In the best possible way, even with an excellent management it is impossible to achieve zero risk of disease outbreak. (CID LINES, n.d) (CID LINES, n.d)When explaining biosecurity, disinfection is made between external and internal biosecurity. External biosecurity has to do with farm keeping in touch with the outside and trying to prevent disease causing agent from entering or leaving farm. Internal biosecurity comprises combat the spread of disease. (code, 2019)

Improving biosecurity at farm level and thus lowering the risk of disease outbreak, has positive effects. First there is the safety of the produced animal product. Second, there is also an improvement in animal welfare due to less disease. Finally and perhaps the most interesting advantage for the farmer is the financial benefit of a disease free production cycle. Less means less veterinary costs and better production result (CID LINES, n.d)

\section{Poultry Rearing}

Poultry rearing is the form of animal husbandry which raises domesticated bird such as chicken, duck, turkey and geese to produce meat or egg for food. It is originated from the Agriculture era poultry mostly chicken are farmed in great numbers. More than 60 billion chickens are killed for consumption annually (SANDERS, 2018).Chicken raised for egg is known as layer, while chickens raised for meat are called broilers. 


\section{Rearing System of Poultry}

There are various systems of rearing of poultry. Among them some are discussed below:

\section{Intensive and Alternative}

According to the World Watch Institute, $74 \%$ of the world's poultry meat, and $68 \%$ of eggs are produced intensively. One alternative to intensive poultry farming is free ranging farming using lower density lower stocking density. Poultry producers routinely use nationally use nationally approved medications, such as antibiotics, in feed and drinking water, to treat disease or to prevent disease outbreak. (National Academies press, 1999)

\section{Indoor Broilers}

Meat chickens commonly called broiler are commonly reared in floor on litter such as wood shavings, rice hulls, indoors in climate controlled housing. These houses are equipped with mechanical system to deliver feed and water to the birds. They have ventilation system and heaters that function as needed. The floor of the house is covered with bedding material consisting of wood chips, rice hulls, or peanut shells. (National chicken council, 2020). Chicken feed consists primarily of corn and soybean meal with the addition of essential mineral and vitamins. No hormones or steroids are allowed in raising chickens. (Poultry and Egg Association, n.d)

\section{Free range Broiler}

Free range broilers are reared under similar conditions to free-range egg laying hens. The benefits of free ranging poultry farming include opportunities for natural behavior such as pecking, scratching, foraging and exercise outdoor space. Free range broilers are often has better leg and heart health.

\section{Study Site and Methodology}

\section{Study site}

The site of study was the sadar upazila of cox's bazar district. Kuluskul, Ramu, Eidghah, and Teknaf were the selected area of the district where the broiler production density is comparatively high. These areas can easily represent the whole cox's bazar district. As it is my home district so it makes easy to collect the true information from the farmer as well as the local authority.

\section{Methodology}

The study had both qualitative and quantitative approach and was based on the desk study, survey and observation. Desk study was done by collecting data from internet, library and government reports. The primary data collection was through survey and own personal observation in the study area. 


\section{Study Framework}

The study framework was developed for guiding the report to successful implementation. (Subedi, 2013)

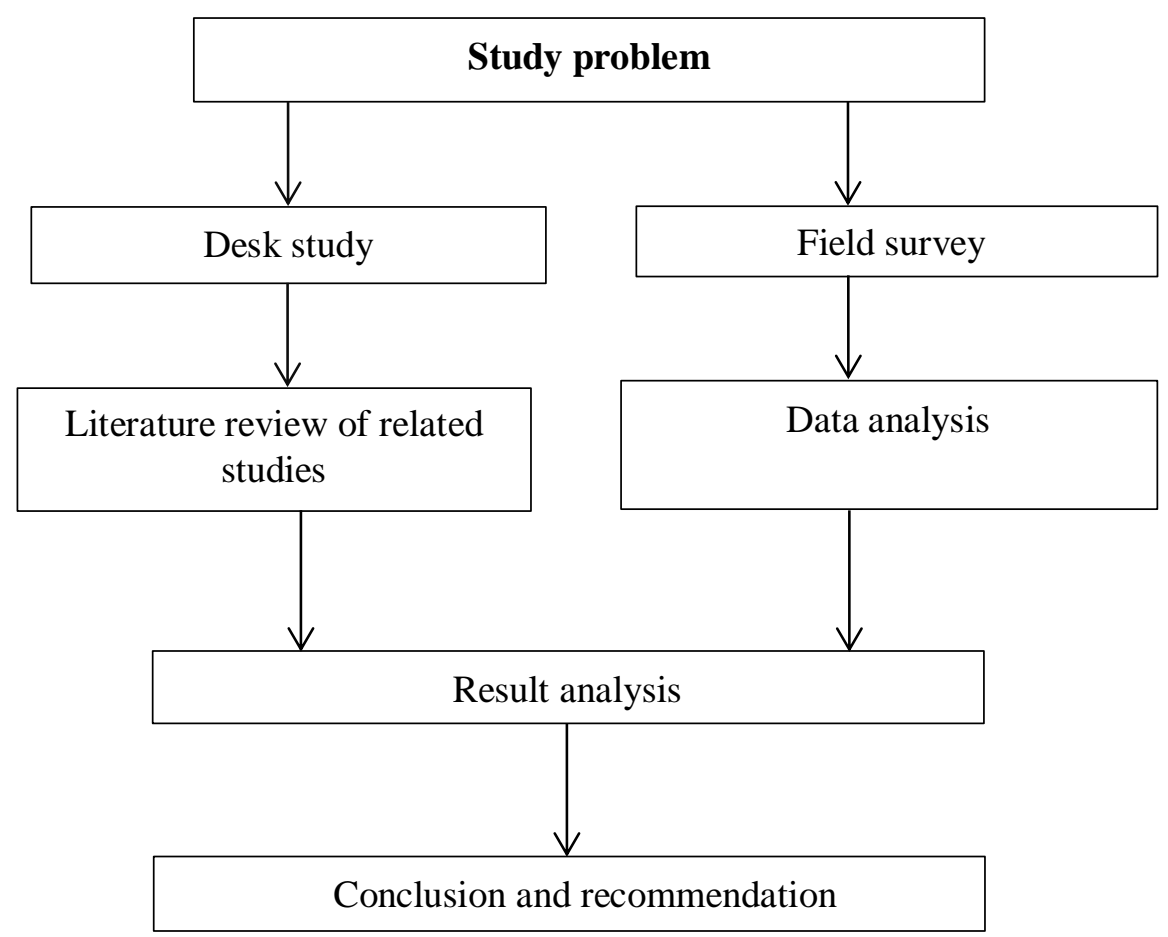

\section{Study Design}

\section{Desk study}

Desk study was used to collect data from existing literature which is necessary to establish strong information for report. The source of information was latest text book, journal, international and national reports such as from the department of livestock service.

\section{Survey}

A survey was done to collect primary data by pre-structured questionnaire which were designed of 20 commercial broiler farmers from 4 places. The questionnaire focused on current hygienic practices applied in their broiler farmers.

\section{Sample Selection and Sample Size}

Based on discussion Kuluskul, Ramu, Eidghah, and Teknaf areas were selected due to their higher number of broiler farm. Within the limited time of field works, the study to survey of 20 commercial farmers.

Thus a stratified sample size $20(5+5+5+5)$ farm from different area of cox's bazar district was chosen purposely due to logistic reason and limitation of the short field study time. 
It was felt that the sample would be sufficient for the study. The results of the study from the sample would give a clue that can be generalized to the research population of the whole district.

\section{Data Tabulation and Analysis}

The excel sheet were used for tabulation of data collected from the survey. The pie chart, bar chart and table were prepared for easy interpretation of the collected data using Microsoft excel program but the analysis in most of the cases was from the all respondents as a single because the answer from all the farmer of different areas was more or less similar.

\section{Result}

This chapter represents the result of survey during the field study. The findings of the survey are presented in the tables for easy interpretation.

\section{Field Survey}

This section draws the broiler farmer characteristics of the distinct namely: Gender, Education background, Flock size, production cycle per year as well as main source of income. A total 20 farmers of selected areas were interviewed in which all location have 5 respondents.

\section{Table 1: Background Information of Farmers}

\begin{tabular}{|c|c|c|c|c|c|c|c|c|c|c|c|c|}
\hline \multirow[b]{2}{*}{ Address } & \multicolumn{2}{|c|}{ Gender } & \multicolumn{4}{|c|}{ Flock Size } & \multicolumn{4}{|c|}{ Production Cycle/year } & \multicolumn{2}{|c|}{ Main Income } \\
\hline & Male & Female & $<500$ & $\begin{array}{l}500- \\
1000\end{array}$ & $\begin{array}{l}1001- \\
1500\end{array}$ & $>1501$ & 4 & 5 & 5.6 & 6 & Yes & No \\
\hline $\begin{array}{c}\text { Kuluskul } \\
\text { Area }\end{array}$ & 4 & 1 & 0 & 3 & 1 & 1 & 0 & 2 & 0 & 3 & 4 & 1 \\
\hline $\begin{array}{c}\text { Ramu } \\
\text { Area }\end{array}$ & 5 & 0 & 3 & 0 & 1 & 1 & 0 & 2 & 1 & 2 & 5 & 0 \\
\hline $\begin{array}{c}\text { Eidghah } \\
\text { Area }\end{array}$ & 3 & 2 & 1 & 2 & 1 & 1 & 1 & 2 & 0 & 2 & 3 & 2 \\
\hline $\begin{array}{c}\text { Teknaf } \\
\text { Area }\end{array}$ & 4 & 1 & 0 & 2 & 2 & 1 & 1 & 0 & 2 & 2 & 3 & 2 \\
\hline Total & 16 & 4 & 4 & 7 & 5 & 4 & 2 & 6 & 3 & 9 & 15 & 5 \\
\hline$\%$ & $80 \%$ & $20 \%$ & $20 \%$ & $35 \%$ & $25 \%$ & $20 \%$ & $10 \%$ & $30 \%$ & $15 \%$ & $45 \%$ & $75 \%$ & $25 \%$ \\
\hline
\end{tabular}


According to the survey, there is higher percentage of male $(80 \%)$ than female $(20 \%)$ in total. This shows that there is more involvement of male than female.

Majority of farmers (35\%) were rearing 501-1000 broilers and there were least number of farmers (15\%) rearing more than 1500 broiler flock at one batch.

Majority (45\%) of the farmers had 6 prOduction cycles per year. Majority of farmers (75\%) have broiler farming main source of income.

\section{Hygienic Practice Awareness and Application in the Farm}

\begin{tabular}{|c|c|c|c|c|c|c|c|c|c|c|}
\hline \multirow{2}{*}{$\begin{array}{l}\text { Hygienic } \\
\text { Practices }\end{array}$} & \multicolumn{2}{|c|}{ Kuluskul Area } & \multicolumn{2}{|c|}{ Ramu Area } & \multicolumn{2}{|c|}{ Eidghah Area } & \multicolumn{2}{|c|}{ Teknaf Area } & \multicolumn{2}{|c|}{ Total } \\
\hline & YES & $\mathrm{NO}$ & YES & $\mathrm{NO}$ & YES & $\mathrm{NO}$ & YES & $\mathrm{NO}$ & YES & NO \\
\hline $\begin{array}{c}\text { All in all } \\
\text { out system }\end{array}$ & 5 & 0 & 4 & 1 & 5 & 0 & 4 & 1 & 18 & 2 \\
\hline $\begin{array}{c}\text { Having } \\
\text { footbath } \\
\text { disinfection }\end{array}$ & 4 & 1 & 4 & 1 & 3 & 2 & 1 & 4 & 11 & 9 \\
\hline $\begin{array}{c}\text { Use of } \\
\text { water } \\
\text { disinfection }\end{array}$ & 5 & 0 & 4 & 1 & 3 & 2 & 5 & 0 & 17 & 3 \\
\hline $\begin{array}{l}\text { Facing } \\
\text { broiler } \\
\text { disease } \\
\text { problem }\end{array}$ & 5 & 0 & 5 & 0 & 5 & 0 & 5 & 0 & 20 & 0 \\
\hline $\begin{array}{l}\text { Antibiotic } \\
\text { use for the } \\
\text { treatment of } \\
\text { broiler }\end{array}$ & 2 & 3 & 0 & 5 & 1 & 4 & 2 & 3 & 5 & 15 \\
\hline $\begin{array}{c}\text { Cleaning } \\
\text { and } \\
\text { disinfection } \\
\text { poultry } \\
\text { farm } \\
\end{array}$ & 5 & 0 & 5 & 0 & 3 & 2 & 5 & 0 & 17 & 3 \\
\hline $\begin{array}{l}\text { Visitor } \\
\text { allowance } \\
\text { to the farm }\end{array}$ & 2 & 3 & 2 & 3 & 1 & 4 & 3 & 2 & 8 & 12 \\
\hline
\end{tabular}

\section{All in All out System}

Majority of the farmers $(90 \%)$ were followed all in all out system.

\section{Foot Bath Disinfection}

There were slightly higher percentage of farmers (55\%) having footbath disinfection than not having. 


\section{Use of Water Disinfection}

Out of 20 farmers interviewed, majority of farmers (85\%) use water disinfection system in the farm in drinking water.

\section{Common Disease Symptom Encountered by the Farmer:}

Common disease symptoms encountered by the farmer included coughing, diarrhea, and lameness. Here we have given the percentage of common problem faced by the farmers in a tabular form.

\begin{tabular}{|c|c|c|c|}
\hline & Coughing & Diarrhea & Lameness \\
\hline Number of farmer & 5 & 11 & $20 \%$ \\
\hline Percentage $(\%)$ & $25 \%$ & $55 \%$ & 4 \\
\hline
\end{tabular}

All the farmers had faced the problem regarding broiler health, among them, diarrhea was the most common symptom (55\%) followed by lameness (20\%) and coughing $(25 \%)$.

\section{Antibiotic Use for the Treatment of Broiler}

Maximum farmers use antibiotic/ antimicrobial (95\%) for the treatment of disease.

\section{Cleaning and Disinfection of Poultry Farm}

Majority of $(85 \%)$ of the farmers clean and disinfect the poultry house thoroughly after each production cycle by cleaning with water flush.

\section{Visitor Allowance into the Farm}

In overall, higher number $(60 \%)$ of the farmers do not allow visitors to enter their farm.

\section{Mortality Percentage}

Mortality percentage faced by the farmer of the farm are given in a tabular form below:

\begin{tabular}{|c|c|c|c|c|}
\hline Mortality & Mortality (<5\%) & Mortality (5-10\%) & $\begin{array}{c}\text { Mortality (10- } \\
\mathbf{1 5 \%}\end{array}$ & Mortality (> 15\%) \\
\hline No of Farm & 1 & 11 & 4 & 4 \\
\hline \% of Farm & $5 \%$ & $55 \%$ & $20 \%$ & $20 \%$ \\
\hline
\end{tabular}

Majority of the farmers (55\%) had observed the mortality of broiler flock 5-10\%. 


\section{Observational Result of Broiler Farm}

\begin{tabular}{|c|c|c|}
\hline Observation & Good & Poor \\
\hline Feed storage condition & 4 & 16 \\
\hline Farm distance with another farm & 10 & 10 \\
\hline $\begin{array}{c}\text { Cleanliness of poultry house } \\
\text { surrounding }\end{array}$ & 8 & 5 \\
\hline Space of given birds & 15 & 8 \\
\hline Availability of farm record & 10 & 6 \\
\hline $\begin{array}{c}\text { Cleanliness and safeties of } \\
\text { dripment used like feeder, }\end{array}$ & 12 & 6 water storage tank \\
\hline $\begin{array}{c}\text { Availability of personal hygiene } \\
\text { equipment }\end{array}$ & 14 & \\
\hline
\end{tabular}

\section{Discussion}

This chapter explains the result from the survey and case studies (interviews). Besides it relates and compares different situation of this district. Current study reveals that, there is lack of awareness regarding the hygienic management of broiler farm in farmers. However aware farmers were not found to adopt the hygienic measure due to different practical measure. On the top of that there is no regular monitoring and inspection by the government authorities, which has further increased problem. There is lack of training for the workers and farmers about the broiler production and management. Though some of the farmers applied personal hygiene measure in the farm, many other may feel the procedure are cumbersome. For example, regular manual washing of cloths and additional cost and time and machine washing is not available due to lack of money and shortage of regular electricity. There may be lack of motivation and willingness in the workers as a result of low incentives, which is also an important factor of hygienic management.

\section{Limitations}

1. Lack of proper support and facility for hygienic management.

2. Political instability.

3. Lack of government monitoring.

4. Lack of implementation of government policy, rules and regulation. 


\section{Conclusion}

The report assessed the good hygienic practices in broiler sector to come up with a clear vision to food safety enhancement in this district. The study concludes that, the hygienic practices used by the different farmers for broiler management is far from the standard recommended by FAO/WHO. To obtain better result, all members in poultry sector need to work together and take this result of this report into their consideration.

\section{References}

Miles, B. e. (2o12). Sanitation program for poultry production. Belgium: Best Veterinary Soluation,INC.

Poultry at a glance:Worlds Poultry Science Association. (n.d). http://wpsa-bb.com/poultry-at-a-glance. Retrieved from World Poultry Science Association: https://wpsa-bb.com/poultry-at-a-glance

S.K.Raha. (2013). Poultry Iindustry in Bangladesh:Present status and Future Potential. Bangladesh: Bangladesh Agricultural university.

CID LINES. (n.d). Sanitation program for poultry production. belgium: BEST VETERINARY SOLUATION.

code, O.-T. A. (2019). Bioseciruty procedure in poultry production. paris: OIE

Holfarce, c. (2002). The health and management of poultry production. International Journal Of Infectious Disease/volume 6, supplement3,2002, 6, 353-357.

Poultry at a glance:Worlds Poultry Science Association. (n.d). http://wpsa-bb.com/poultry-at-a-glance . Retrieved from World Poultry Science Association: https://wpsa-bb.com/poultry-at-a-glance

S.K.Raha. (2013). Poultry Iindustry in Bangladesh:Present status and Future Potential. Bangladesh: Bangladesh Agricultural university.

Subedi, K. P. (2013). An assessment of Good hygeinic practices of broiler chain of kaski district. WAGENINGEN: VAN HALL LARENSTEIN UNIVERSITY OF APPLIED SCIENCES .

"Animal Welfare For Broiler Chicken". National Council. Retrieved June 21,2012

" Poultry Industry Frequently Asked Question" . U.S Poultry and Egg Association. Retrieved June 21,2012

Global Animal Slaughter Statistic and Charts. Faunalytics.October 10,2018.Retrieved November5,2019 